\title{
An Assessment of the Practice and Its Determinant Factors of Active Learning Practices in EFL Classes: A Case Study on English Language Course in Derbre Markos College of Teacher Education
}

\author{
Yewulsew Melak \\ Debre Markos University, College of Social Science and Humanities., P.O.Box 269, Debre Markos,Ethiopia
}

\begin{abstract}
The study aimed to assess the practice and its determinant factors of active learning in EFL Learners of DebreMarkos college of Teacher Education. 80 prospective teachers and 18 English language teacher educators were participants of the study. The data was collected through questionnaire, interview and observation. Percentage, mean and qualitative analysis were used to analyze data. The findings of the study revealed that both Teacher educators and prospective teachers have favorable beliefs towards active learning. The different active learning strategies were sometimes practiced. That is, pair work, group work, discussion, lecture and question and answer were employed. The magnitude of practicing active learning in EFL classes of the respective college was low. Among factors that influence effective implementation of active learning: lack of facilities and materials, tendency towards lecture method, shortage of time, prospective teachers' and teacher educators' lack of interest to implement active learning, lack of trainings and the design of training modules were the major ones. Generally, to solve the problems encountered in the effective implementation of active learning: continuous and extensive orientations and training, in the form of workshops and seminars should be offered to teacher educators and prospective teachers; facilities like language laboratory and standard library equipped with recent materials should be established; Teachers should prepare and utilize instructional materials, training modules should be prepared in a way to facilitate active learning implementation.
\end{abstract}

Keywords: Active Learning, Determinant Factors, EFL

DOI: $10.7176 /$ RHSS/10-9-04

Publication date:May $31^{\text {st }} 2020$

\section{Introduction}

In education, the term "assessment" refers to the wide variety of techniques or tools that teacher-educators use to evaluate learning progress or education needs of students. "Assessment is a central feature of teaching and the curriculum. It powerfully frames how students learn and what students achieve" (David Boud et al., 2010, p. 1). Traditionally, it means assessing learning of students'. However, because assessments play a very significant role in students' understanding, researchers suggested a paradigm shift of assessment from "testing learning of students to assessing for students learning" (Birenbaum \& Feidman, 1998, p. 92). There is widespread agreement that assessment is an integral part of any effective educational system but the debate about assessment-practices mainly centers on the challenges and complexities assessment poses in implementing it effectively.

Active learning is a form of learning that directly engaged the student in the learning process. It is an approach that gives a due emphasis to the learner to be an actor in learning and searching solutions rather than to be dependent only on the teacher (Silberman, 1996). Even though all learning is in some sense active, but active learning refers to the level of engagement by the student in the instructional process. An active learning environment requires students and teacher to commit to a dynamic partnership in which both share a vision of responsibility for instruction (Capel, 1995).

\subsection{Statement of the Problem}

There were numerous studies that have been conducted in different corners of the world to solve problems in implementation of active learning in schools. For instance, Taye (2008) and Bethel (2011) conducted their research on practices and perceptions of active learning in Dilla University and school communities in implementing active learning in Bulbula secondary school respectively and their findings revealed that even school communities have positive perceptions in the implementations of active learning; its implementation in English lessons still needs further investigation. In their finding, they disclosed that teachers and instructors have theoretical understandings about active learning. In relation to this, there were also other researchers who conducted their M.A thesis regarding student centered/ALM; among them: Moges, (2007); Binyam, (2014); and Arikew, (2015) did in the same area. Their studies focused on large class size, shortage of time, awareness problems and readiness to implement active learning methodology are among the challenges affecting its implementation in English classes. In the same way, Girma (2013) and Ayele (2014) conducted their thesis on same issue and their findings revealed that active learning failed in to practice in schools due to scarcity of time to cover the portion, students attention 
on exam oriented topics and lack of adequate materials. As stated above, some of the problems have not been assessed until now.

\subsection{Objectives of the Study}

Therefore, the objective of this study was to assess assessment practice and its determinant factors of active learning practices in EFL learners

\section{Research Design and Methodology}

\subsection{Research Design}

The study employed descriptive survey designs to collect, process, analyze and present the data. Thus, descriptive survey design was employed by using mixed method of data collecting and describing in organized way including the characteristics, features or facts about the given population in this study to make the obtained data more feasible and preferable to examine the present situation on perceptions and practices of EFL learners.

\subsection{Research Setting and sampling}

The setting for this investigation was Derbre Markos College of Teacher Education. The target population of this study included of EFL teachers and students of EFL. According to the information obtained from the department of language, there are 160 third year language students. Accordingly, 80 prospective teachers or $50 \%$ were included in the study. With regard to their sex, 45 of them were females and the rest 35 were males. Regarding teacher educators as respondents there are 18 English language teacher educators' in the college; all of them were included in the study.

In order to get sample population, purposive sampling and random sampling were used in the study. Prospective teacher respondents were selected purposely from third year language stream for the study by using purposive sampling. These groups were selected on the assumption that third year students with five semesters stay in the college have better experience about Active learning implementation than first year and second year students.

\subsection{Data Gathering Tools and Procedures}

The study employed mainly qualitative and quantitative data collection tools. The relevant data were collected through different instruments, such as, observation, questionnaires and interviews. Thus, the researchers preferred the qualitative method to describe the data that were collected by semi- structured interviews and the quantitative method to describe all close ended questionnaires and observation checklist.

A questionnaire, which is a principal survey instrument, was used in this study. It was designed to reveal teacher educators' and prospective teachers' personal beliefs about the practice of active learning and factors that affect the implementation of active learning. Thus, two kinds of questionnaire were used; one for teacher educators and the other for prospective teachers. The researcher used close-ended type questions. Respondents were required to rate the degree of their agreements or disagreement to each statement on a 5-point Likert scale from 5 (strongly agree) to 1 (strongly disagree) about active learning implementation. In fact, a likert scale was originally developed to measure the respondents' favorable or unfavorable attitudes towards the object of interest. However, as Bernat (2005) asserts, its scope has been extended to wider cognitive and affective variables including beliefs.

Interview was also one of the selected data collecting instruments for the sake of assessing challenges and factors of active learning practices in EFL learners. It is clear that interview can provide data in-depth that is not possible with questionnaire. Data from interview were supplemented with other responses in the application of the study. Therefore, to support and cross-check the findings from the questionnaire, well-constructed semi-structured interview questions were prepared to collect data in depth. A total of 4 teacher Educators and 15 randomly selected prospective teachers from the sample subjects were involved in the interview.

\subsection{Data Analysis Procedures}

Both quantitative and qualitative methods of data analysis were employed in order to answer the research questions and to attain the objectives. The quantitative data were collected, coded, tabulated, analyzed, described and interpreted in a manner that it supports finding obtained from the study. First, the data gathered through close ended questionnaire by using a five-point Likert Scales (strongly agree, agree, undecided, disagree and strongly disagree) as suggested by Best (2003) and Kothari (2004) were tabulated in terms of frequency, percentage and mean value (to compute the proportionality of individual response of the items) by assessing the scale value to each of the five scale responses. Data obtained from the interview was analyzed descriptively.

\section{Results}

What we recognize from table 1 and 2 is that there are many factors affecting the application of active learning in EFL classroom. Among them, most respondents, which are $76.92 \%$, Lack of facilities and materials were rated as 
most serious problem which hinders the implementation of active learning practice in the classroom. The other is teacher educators' and prospective teachers' tendency to use traditional lecture method, lack of training, shortage of time to practice it, teacher educators' and prospective teachers' lack of interest to implement active learning and the design of teaching modules rated with percentages $69.25 \%, 69.23 \%, 61.54 \%$ and $61.54 \%$ respectively.

Supporting this study some scholars like Jakayinfa (2013), Aschalew (2012), Birhanu (2010) and Taye (2008) emphasizes that lack of adequate teaching materials, teacher educators' and prospective teachers' tendency to use traditional lecture method and lack of training were found as challenges of teacher educators' to practicing active learning methodologies in their classes. David, Sylvester \& Olatunji, 2013; Yara, 2009; and Reinke \& Moseley, 2002;) identified that the teachers have received short- and long-term trainings in active learning methodologies both in pre-service and in-service trainings they will be more likely to practice active learning.

Teacher educators' and prospective teachers' tendency to traditional lecture method is the other problem which was raised as an obstacle in the implementation of active learning by many prospective teachers and teacher educators. With respect to this problem, the two groups of respondents again agreed that the tendency of prospective teachers and teacher educators to the traditional method of teachers' lecture or explanation was the second major problem negatively influencing the effective implementation of active learning. Supporting this, other researcher, Plass (1998) explains the tendency of teachers to the traditional lecture method.

In relation to the organization of training modules, a great number of scholars for example, Mukalel (1998) cited in Amenu (2005) stressed that the conduciveness of the organization of curriculum materials play a crucial role for effective implementation of active-learning. However, both respondents replied in the questionnaires that the design of training modules is one of the most serious problems, which affects the implementation of active learning. Similarly, teacher educators and prospective teachers during the interview reported that the training modules were not prepared along active learning lines.

Table 1: Percentage and Mean values of Factors Affecting Teacher Educators' Implementation of Active Learning.

\begin{tabular}{|c|c|c|c|c|c|c|c|c|c|c|c|}
\hline \multirow[t]{2}{*}{ No } & \multirow[t]{2}{*}{ Items } & \multicolumn{2}{|c|}{$\begin{array}{c}\text { Most } \\
\text { serious }=4\end{array}$} & \multicolumn{2}{|c|}{ Serious $=3$} & \multicolumn{2}{|c|}{$\begin{array}{l}\text { Undecided } \\
=2\end{array}$} & \multicolumn{2}{|c|}{$\begin{array}{c}\text { Not } \\
\text { serious }=1\end{array}$} & \multirow[t]{2}{*}{$(L v x f)$} & \multirow[t]{2}{*}{$\frac{\mathrm{X}=\operatorname{Lvxf}}{\mathrm{N}}$} \\
\hline & & No & $\%$ & No & $\%$ & No & $\%$ & No & $\%$ & & \\
\hline 1 & $\begin{array}{l}\text { Teacher educators' and } \\
\text { prospective teachers' } \\
\text { tendency to use traditional } \\
\text { lecture method. }\end{array}$ & 9 & 69.23 & 3 & 23.08 & 1 & 7.69 & & & 47 & 3.62 \\
\hline 2 & \begin{tabular}{llrr|}
$\begin{array}{l}\text { Shortage } \\
\text { practice }\end{array}$ & & af & time to \\
learning & & & \\
\end{tabular} & 8 & 61.54 & 5 & 38.46 & & & & & 47 & 3.62 \\
\hline 3 & Large classroom size & 1 & 7.69 & 4 & 30.77 & & & 8 & 61.54 & 24 & 1.85 \\
\hline 4 & $\begin{array}{l}\text { Lack of facilities and } \\
\text { materials }\end{array}$ & 10 & 76.92 & 3 & 23.08 & & & & & 49 & 3.77 \\
\hline 5 & $\begin{array}{l}\text { Lack of supervision and } \\
\text { support from college } \\
\text { administration. }\end{array}$ & & & 6 & 46.15 & 2 & 15.38 & 5 & 38.46 & 27 & 2.08 \\
\hline 6 & $\begin{array}{l}\text { Teacher educators and } \\
\text { prospective } \\
\text { teachers lack of interest to } \\
\text { implement Active learning }\end{array}$ & 8 & 61.54 & 2 & 15.38 & 1 & 7.69 & 2 & 15.38 & 42 & 3.23 \\
\hline 7 & $\begin{array}{l}\text { Teacher educators' belief } \\
\text { and perception about } \\
\text { active learning }\end{array}$ & 2 & 15.38 & 3 & 23.08 & 2 & 15.38 & 6 & 46.15 & 23 & 1.77 \\
\hline 8 & $\begin{array}{l}\text { Prospective teachers' } \\
\text { belief and perception } \\
\text { about active learning }\end{array}$ & 4 & 30.77 & 2 & 15.38 & 2 & 15.38 & 5 & 38.46 & 33 & 2.54 \\
\hline 9 & $\begin{array}{l}\text { The design of teaching } \\
\text { modules }\end{array}$ & 2 & 15.38 & 8 & 61.54 & & & 3 & 23.08 & 35 & 2.69 \\
\hline 10 & $\begin{array}{l}\text { Lack } \\
\text { training/workshops, } \\
\text { seminars/etc }\end{array}$ & 1 & 7.69 & 19 & 69.23 & & & 3 & 23.08 & 34 & 2.62 \\
\hline 11 & Rigidity of time table & 4 & 30.77 & 2 & 15.38 & 2 & 15.38 & 5 & 38.46 & 31 & 2.38 \\
\hline 12 & $\begin{array}{l}\text { Diversity of prospective } \\
\text { teachers' interest }\end{array}$ & 2 & 15.38 & 4 & 30.77 & 3 & 23.08 & 4 & 30.77 & 30 & 2.31 \\
\hline
\end{tabular}


Table 2: Percentage and mean Values of Factors Affecting Prospective Teachers' Participation.

\begin{tabular}{|c|c|c|c|c|c|c|c|c|c|c|c|}
\hline \multirow[t]{2}{*}{ No } & \multirow[t]{2}{*}{ Items } & \multicolumn{2}{|c|}{$\begin{array}{c}\text { Most } \\
\text { serious }=4\end{array}$} & \multicolumn{2}{|c|}{ Serious $=3$} & \multicolumn{2}{|c|}{$\begin{array}{l}\text { Undecided } \\
\quad=2\end{array}$} & \multicolumn{2}{|c|}{$\begin{array}{c}\text { Not } \\
\text { serious }=1\end{array}$} & \multirow[t]{2}{*}{$(\operatorname{Lv} x f)$} & \multirow[t]{2}{*}{$\frac{X=\operatorname{Lvxf}}{N}$} \\
\hline & & No & $\%$ & No & $\%$ & No & $\%$ & No & $\%$ & & \\
\hline 1 & $\begin{array}{l}\text { Teacher educators' and } \\
\text { prospective teachers' } \\
\text { tendency to use traditional } \\
\text { lecture method }\end{array}$ & 19 & 26.39 & 36 & 50 & 9 & 12.5 & 8 & 11.1 & 210 & 2.92 \\
\hline 2 & $\begin{array}{l}\text { Shortage of time to practice } \\
\text { active learning }\end{array}$ & 37 & 51.39 & 17 & 3.61 & 3 & 4.17 & 15 & 20.08 & 220 & 3.06 \\
\hline 3 & Large class size & 16 & 22.22 & 12 & 16.67 & 7 & 9.72 & 37 & 51.39 & 151 & 2.10 \\
\hline 4 & $\begin{array}{l}\text { Lack of facilities and } \\
\text { materials }\end{array}$ & 41 & 56.94 & 23 & 31.94 & 8 & 11.11 & & & 249 & 3.46 \\
\hline 5 & $\begin{array}{l}\text { Lack of supervision and } \\
\text { support from the college } \\
\text { administration }\end{array}$ & 21 & 29.17 & 16 & 22.22 & 11 & 11.1 & 24 & 33.33 & 178 & 2.47 \\
\hline 6 & $\begin{array}{l}\text { Teacher educators' and } \\
\text { prospective teachers' lack } \\
\text { of interest to implement } \\
\text { Active learning }\end{array}$ & 16 & 22.22 & 35 & 48.61 & 13 & 18.06 & 9 & 12.5 & 204 & 2.83 \\
\hline 7 & $\begin{array}{l}\text { Teacher educators' belief } \\
\text { and perception }\end{array}$ & 6 & 8.33 & 18 & 25 & 11 & 11.1 & 37 & 51.39 & 137 & 1.9 \\
\hline 8 & $\begin{array}{l}\text { Prospective teachers' belief } \\
\text { and perception }\end{array}$ & 9 & 12.5 & 15 & 20.08 & 15 & 20.08 & 33 & 45.83 & 144 & 2.00 \\
\hline 9 & $\begin{array}{l}\text { The design of teaching } \\
\text { modules }\end{array}$ & 43 & 59.72 & 14 & 19.44 & 8 & 11.11 & 7 & 9.72 & 237 & 3.29 \\
\hline 10 & $\begin{array}{l}\text { Lack of training, workshops, } \\
\text { seminars etc }\end{array}$ & 36 & 50 & 16 & 22.22 & 5 & 6.94 & 15 & 20.08 & 217 & 3.01 \\
\hline 11 & Rigidity of time table & 12 & 16.67 & 30 & 41.67 & 12 & 16.67 & 18 & 25 & 180 & 2.50 \\
\hline 12 & $\begin{array}{l}\text { Diversity of prospective } \\
\text { teachers' interest }\end{array}$ & 25 & 34.72 & 20 & 27.78 & 16 & 22.22 & 11 & 11.1 & 203 & 2.82 \\
\hline
\end{tabular}

\section{Discussion}

In this study, like the previous research findings in the country For example, Aschalew (2012), Gara and Asrat (2011), Daniel (2007), Ministry of Education (2002, 2006, 2007), Taye (2008), and Birhanu (2010)) that indicated there was less or no practice of active learning methodologies by teachers of sample participants as sample schooling institutions, the present study came up with findings that clearly indicated the practice of active leaning methodologies by teacher participants of the study at both the teacher education colleges.

Some scholars like Jakayinfa (2013), Aschalew (2012), Birhanu (2010) and Taye (2008) emphasizes that lack of adequate teaching materials, teacher educators' and prospective teachers' tendency to use traditional lecture method and lack of training were found as challenges of teacher educators' to practicing active learning methodologies in their classes. David, Sylvester \& Olatunji, 2013; Yara, 2009; and Reinke \& Moseley, 2002;) identified that the teachers have received short- and long-term trainings in active learning methodologies both in pre-service and in-service trainings they will be more likely to practice active learning.

However, the study also came up with findings that are consistent with other previous research findings. I.e. the teacher participants of this study are practicing active learning methodologies in their classes as a result of four determinant factors. The first one is, the teacher's engagement in educational assessment techniques. We can mention studies that support the hypothesis that if teachers engage in assessment activities they will be more likely to practice active learning methodologies in their classes see, for example, (Maria \& Jorge, 2012; Springer et al, 1999; Gray, 2009; Birhanu, 2013; Abiy, 2013; and Desalegn, 2014). The second one is, the teachers are having positive attitude towards active learning methodologies. we can mention studies that support the hypothesis that if teachers have positive attitude towards active learning methodologies they will be more likely to practice active learning methodologies in their classes see, for example, (David, Sylvester \& Olatunji, 2013; Yara, 2009; and Reinke \& Moseley, 2002;). The third one is, the teachers have received short- and long-term trainings in active learning methodologies both in pre-service and in-service trainings. we can mention studies that support the hypothesis that if teachers have received short- +and long-term trainings on active learning methodologies they will be more likely to practice active learning methodologies in their classes see, for example, (Postareff, Lindblom-Ylanne \& Nevgi, 2006; and Farooq \&, Shahzadi ,2006). The fourth one is, the teachers are accessing to 
inputs (material and administrative support). we can mention studies that support the hypothesis that if teachers have received input they will be more likely to practice active learning methodologies in their classes see, for example, (Cohen, Raudenbush, \& Ball, 2002; Odes, 2014; Seglam, 2011; and Egwunyenga \& Enueme, 2008).

Indeed, therefore, it would be reasonable to argue that the practice of active learning methodologies by teacher participants of this study at the two colleges will have unprecedented significant impact up on the learning/academic achievement of their students though argued without having academic achievement of students treated as one variable of this study. But, there are ample findings that support when teachers practice active learning methodologies in their classes there would be positive consequences including better academic achievement of students (Michale et al, 2009;,Stewart et al, 2010).

In the same way, instructional materials are other elements to be considered in the implementation of active learning, because, the availability and unavailability of instructional materials can facilitate or hamper the effective implementation of active learning (Amare, 1998). This finding also reached the same conclusion in that the two groups of respondents disclosed the negative influence of instructional materials on the effective implementation of active learning.

Teacher educators' and prospective teachers' tendency to traditional lecture method is the other problem which was raised as an obstacle in the implementation of active learning by many prospective teachers and teacher educators. With respect to this problem, the two groups of respondents again agreed that the tendency of prospective teachers and teacher educators to the traditional method of teachers' lecture or explanation was the second major problem negatively influencing the effective implementation of active learning. Supporting this, other researcher, Plass (1998) explains the tendency of teachers to the traditional lecture method. Many teachers perceived teaching as a transmission process where the teacher transmits knowledge to students and the students receive that knowledge. This implies that the effectiveness of the teacher is evaluated on the extent to which he/she follows the prescribed syllabus and covers the portion in the determined time schedule.

Similarly, Evan and Nation, cited in Amenu (2005), noticed that most prospective teachers fall into the old cultural trap and expect their instructors to lecture them in traditional classroom manner; generally, this problem was highly observed in this study.

Shortage of time as hindering factor to fully implement active learning was supported by the majority of the respondents. This problem was widely raised during the interview with teacher educators; since they are overloaded and becomes difficult to plan, prepare and implement different active learning strategies. On the other hand, prospective teachers' also highlighted problem of time to implement active learning as it makes them too busy and overloaded with different group or individual activities/tasks. In the same way, teacher educators' and prospective teachers' lack of interest negatively affects the implementation of Active learning. During the interview, two of the respondents commented on each other that it is the other major problem that affects the effective implementation of active learning in teaching/learning English language.

In relation to the organization of training modules, a great number of scholars for example, Mukalel (1998) cited in Amenu (2005) stressed that the conduciveness of the organization of curriculum materials play a crucial role for effective implementation of active-learning. However, both respondents replied in the questionnaires that the design of training modules is one of the most serious problems, which affects the implementation of active learning. Similarly, teacher educators and prospective teachers during the interview reported that the training modules were not prepared along active learning lines. They further reported that there are insufficient activities and exercises that invite the active participation of learners, too much content to be covered and the poor distribution of modules are the major problems identified in the modules. The results of questionnaire and interview disclose that the preparation and distribution of English language modules do not facilitate the implementation of active learning.

Scholars have suggested that, if education is to be successful, next to curriculum, teacher training is of special significance, to maximize the development of changes in education (Smyth, 1987). Inline with this idea Kakkar (1995) stated that the changing role of teachers and the dynamics in education for the teacher must grow in profession and practice of teaching through in service and pre-service education programs. However, in this study, the data from the questionnaire and results from interview showed that lack of training seriously affects the effective implementation of active learning.

Again, it is also reasonable to hope that the students of the two teacher education colleges are the would be teacher candidates, so, they will be role modeling the practice of active learning methodologies of their teachers. As a result, when they happen to be teachers the will be more likely to practice active learning methodologies in their classes. So, the vicious circle as an impact of teacher participants up on their future teacher- students will be positive and can be considered as there is a laying of a strong foundation in terms of the production of capable and efficient teachers to the zones, region and to the nation at large.

The crux of the matter is, the practice of the two teacher education colleges in terms of the application and utilization of active learning methodologies can be taken as an exemplary great lesson where other higher education institutions and other schooling institutions found in Ethiopia can share, learn and practice the trend if 
we need to realize quality education in the country. Furthermore, it is only when we practice at all levels of education that we can achieve the goal of ESDPIII i.e. Universal access to quality primary education by 2015 and to quality secondary education by 2025 ( Ministry of Education, GEQUIP, 2007). In this regard, therefore, it will be reasonable to hope that similar colleges and other universities of Ethiopia will came in the future with similar trend of the practice of active learning methodologies serving as one instrument which the ministry of Education, the government, educators and stakeholders are aspiring for the realization of quality education in the country.=

\section{Summary and Conclusions}

Based on the major findings of the study, the following conclusions were drawn.

- Both teacher educators and prospective teachers have favorable beliefs to use active learning practices. Hence, it can be concluded that their beliefs were not the major barriers in implementing active learning.

- The result of the study revealed that the main implementers of active learning, namely, teacher educators and prospective teachers lack the necessary knowledge and practical skills on active learning.

- The quality of training modules is one component in the effective implementation active learning. Whereas, the finding depicted that the training modules were not prepared in a way that facilitate the implementation of active learning because they have not been organized in such a way that the learners can actively involve in their learning task.

- The major problems accountable for the low practice of active learning were found to be lack of facilities and instructional materials, tendency of teacher educators' and prospective teachers' to favor traditional lecture method, shortage of time, teacher educators' and prospective teachers' lack of interest to implement active learning and lack of in service trainings like seminar and workshops.

\section{Recommendations}

- The magnitude of practicing of active learning in English classes of the selected college found to be low and the degree of exercising different active learning instructional strategies was not adequate. Therefore, it is important to give orientation and training on the teaching methodologies in general and on active learning approach in particular for teacher educators and prospective teachers.

- In relation to the design of training modules, the organization of teaching modules was not conducive to implement Active learning. Therefore, the modules should be developed in a way to enable learners enrich themselves in knowledge and skill through active learning approach.

\section{References}

Amare, et al (1998) "Teachers' Perceptions of Educational Problems in Ethiopia: Visions for 21 st Century. Addis Ababa: IER

Amenu Olijira (2005). "The implementation of Active learning Approach in the Teacher Colleges of Oromia Region". Addis Ababa University (unpublished Masters Thesis).

Bernat, E (2005) Beliefs about Language Learning: "Current Knowledge, Pedagogical Implications, and New Research Directions" Available (online) http://teslej.org/ej33/al.html.

Best, T. W. and Kahn, r.v. (2003). Research Methods in Education. New Delhi: Prentice Hall.

Bonewell, C (2003) "Active Learning: Creating Excitement in the Classroom" From http://www .Macom. CCmius/ are/D hMa terialsactivelearninghtm. Accessed on March, 2009.

Borg, M (2001) "Teachers Beliefs" ELT Journal. vol 55/2

HDP (2004). Higher Diploma Programme. Addis Ababa: Ministry of Education

Margaret E.G. (2005). Learning and Institution: Theory into Practice. Newjersey: Pearson Education inc.

MOE (2003). TESO Pre-service Committee a Notional Curriculum Guideline for Preservice Teacher Education Programms. AAU (Unpublished).

Nardos Abebe (2000). Issues and Methods and Materials in Teaching Primary School Subject. Addis Ababa: AAU. Orlich, D et al (2001). Teaching Strategies: A Guide to Better Instruction (16 $6^{\text {th }}$ ed) Boston: Hough ton Mefflin Company.

Plass, H (1998). "The Learner Centered Classroom" Quality Education.

Richards, 1C. and Rodgers, T.S. (2001) Approaches and Methods in Language Teaching. New York: Cambridge University Press.

Silberman, M (1996). Active Learning 101 Strategies to teach any Subject. Boston: Ally and Bacon.

Smylie, M. et al (1999). Preparing Teachers as Agents of Change. Chicago: NSSE. (1983). Fundamental Concepts of Language Teaching. Oxford: Oxford Universtiy Press.

Taye Geresu (2008) "Perception and Practices of Active Learning in EFL Classroom" Addis Ababa University; M.A. Thesis (Unpublished)

Temechegn Engida (2002). "Teaching Primary School Subject using Learner Centered Methodology. In Ethiopian Journal of Educational Researchers Association vo. 1. No 1 Addis Ababa.

Transitional Government of Ethiopia (1994). New Education and Training Policy (NETP). Addis Ababa: EMPDA. 